\title{
Interaction of Immune System Protein with PEGylated and Un-PEGylated Polymeric Nanoparticles
}

\author{
Matthewos Eshete ${ }^{*}$, Kayla Bailey ${ }^{1}$, Tuyen Duong Thanh Nguyen ${ }^{2,3}$, \\ Santosh Aryal ${ }^{2,3}$, Seong-O Choi ${ }^{2,4}$ \\ ${ }^{1}$ Department of Chemistry, Mississippi Valley State University, Itta Bena, MS, USA \\ ${ }^{2}$ Nanotechnology Innovation Center of Kansas State (NICKS), Kansas State University, Manhattan, KS, USA \\ ${ }^{3}$ Department of Chemistry, Kansas State University, Manhattan, KS, USA \\ ${ }^{4}$ Department of Anatomy and Physiology, Kansas State University, Manhattan, KS, USA \\ Email: *meshete@mvsu.edu
}

How to cite this paper: Eshete, M., Bailey, K., Nguyen, T.D.T., Aryal, S. and Choi, S.-O. (2017) Interaction of Immune System Protein with PEGylated and Un-PEGylated Polymeric Nanoparticles. Advances in Nanoparticles, 6, 103-113.

https://doi.org/10.4236/anp.2017.63009

Received: June 20, 2017

Accepted: August 5, 2017

Published: August 9, 2017

Copyright $\odot 2017$ by authors and Scientific Research Publishing Inc. This work is licensed under the Creative Commons Attribution International License (CC BY 4.0).

http://creativecommons.org/licenses/by/4.0/

\begin{abstract}
Biodegradable Nanoparticles (NPs) are under intense investigation due to their potential application in targeted drug delivery. Upon their entry to the biological system, they encounter the immune system, which limits their availability at the intended site. Most importantly, the innate immune system is the one that acts as the first line of defense against foreign materials. It can be activated by collectin proteins which recognize the structural pattern of polysaccharide on the surface of microorganisms. NPs may interact with these proteins in a similar way, and the interaction may lead to beneficial outcomes in vaccine delivery. On the other hand, in targeted drug delivery, it is desirable for the NPs not to be recognized as foreign material as this may lead to their fast elimination from the system through mechanism such as opsonization. We investigated the interaction of PEGylated and un-PEGylated PLGA NPs with Recombinant Human Mannose-Binding Protein (HMBP) in an effort to understand the effect of surface modification on their binding to the protein. Results show that both PLGA-COOH and PLGA-PEG-NH $\mathrm{N}_{2}$ bind to HMBP as studied using dynamic light scattering (DLS), fluoresce and UV-vis spectroscopy. However, their binding is shown to have different effect on the structure of the protein. Study done using fluorescence spectroscopy displayed a decrease in fluorescence emission of the protein upon binding to PLGA-COOH. On the other hand the fluorescence emission of the protein increased upon binding to the PLGA-PEG- $\mathrm{NH}_{2}$ indicating conformational changes in the protein structure.
\end{abstract}

\section{Keywords}

Nanoparticles, Mannose-Binding Protein, Poly (L-Lactic-Co-Glycolic Acid), Nanoparticle Protein Interaction 


\section{Introduction}

Particles with the size ranging from $1 \mathrm{~nm}$ to $100 \mathrm{~nm}$ are called nanoparticles (NPs). They possess enhanced or altered physical, chemical and biological properties which make them superior in different applications than the corresponding bulk counterparts [1]-[9]. Physical properties of materials at the nano scale are different from their bulk properties; therefore properties of NPs such as reactivity, catalytic activity, strength, etc. could be altered fundamentally. Because of NPs' unique properties, there has been a dramatic increase in emerging new use of NPs for various applications, including drug delivery. Biodegradable polymeric NPs such as poly (D, L-lactide-co-glycolide) (PLGA), polylactic acid (PLA), gelatin and poly-alkyl-cyano-acrylates (PACA) are attracting a great deal of research interest due to their potential to deliver therapeutic molecules such as vaccines, drugs, and genes to target cells [10]-[16]. The use of biodegradable NPs in drug delivery systems arises from their unique and various properties including biocompatibility, versatility, better drug stability, encapsulation and controlled release. Several studies for particle uptake by target cells have demonstrated that properties of NPs such as shape, surface modification, and particle size significantly increase the intracellular uptake rate compared to unmodified NPs [17] [18] [19] [20]. On the other hand, various studies have also shown that NPs interact with the host cell immune systems and lead to either immune stimulation or immune suppression; some NPs may be unrecognized by the immune system and remain in circulation for a long period [21]-[28]. Each of this may have advantages and disadvantages depending on the intended purpose of the NPs delivery system [29] [30] [31]. The complement or mannose binding pathway, a part of the pathways in the innate immune systems, is one of the first lines of defense for the host cells that the NPs drug delivery system would encounter. The Mannose-binding Lectin pathway is activated by oligosaccharide binding collectin proteins. Their carbohydrate binding domain recognizes patterns of polysaccharides on the surface of microorganisms and binds to them. Using their other domain, they recruit proteins or bind to host cell receptors leading to the activation of a cascade of reactions in the immune complement system, thereby resulting in various immunological responses, such as the removal of the invading microorganisms by the process including phagocytosis [32] [33] [34]. Therefore, Lectin pathway plays an important role in modulating immunogenicity of foreign molecules. We hypothesized that collectin proteins could recognize and bind to specific structural features of NPs as they bind to their target molecules on the surface of microorganisms. This could be one of the mechanisms that trigger various immunological responses of NPs. This study explored the binding of modified and unmodified biodegradable NPs (PLGA-COOH and PLGA-PEG-NH $\mathrm{N}_{2}$ ) with Recombinant Human MannoseBinding Protein C (HMBP) in an effort to understand the effect of surface modification of the NPs on protein binding. The protein binding to NPS was examined by dynamic light scattering (DLS), fluorescence, and UV-vis spectroscopy. 


\section{Materials and Experimental Methods}

\subsection{Materials}

Unmodified poly (D, L-lactide-co-glycolide) (PLGA-COOH) and modified (PLGA-PEG-NH2) NPs were prepared in Dr. Aryal's Lab by nanoprecipitation technique as reported elsewhere [15] [35] [36]. In brief, $1 \mathrm{mg}$ of PLGA-COOH in $100 \mu \mathrm{L}$ acetonitrile was added dropwise into $1 \mathrm{~mL}$ Milli-Q water under magnetic stirring. The mixture was stirred continuously overnight to evaporate organic solvent. The PLGA-COOH nanoparticles were further purified using Amicon Ultra-4 centrifugal filter (Millipore, MA) with a molecular weight cutoff of $1000 \mathrm{kDA}$. Modified PLGA-PEG-NH $\mathrm{NH}_{2}$ were prepared by adding $100 \mu \mathrm{L}$ PLGA ( $1 \mathrm{mg}$ ) into $2 \mathrm{~mL} 4 \%$ ethanol containing $200 \mu \mathrm{g}$ DSPE-PEG-NH, $260 \mu \mathrm{g}$ Egg-PC under magnetic stirring condition at $60^{\circ} \mathrm{C}$, followed by addition of $1 \mathrm{~mL}$ Milli-Q water and purified as described above (TEM image of representative sample shown in Figure 1). Recombinant Human Mannose-Binding Protein C/MBL-2 (HMBP) was purchased from Novoprotein Scientific (Summit, NJ) with Greater than 95\% purity as determined by reducing SDS-PAGE (Amino acid sequence of HMBP is shown on Table 1). All chemicals used for this experiment were reaction grade. Protein A, HRP conjugate was purchased from EMD Millipore (Billerica, MA). Mannan from Saccharomycse cerevisiae, ABTS (2,2'-azino-di [3-ethylbenzthiazoline] sulfonate, Higher binder 96 well plate, and Greiner UV transparent 96 well plate were purchased from Sigma-Aldrich (St. Louis, MO).

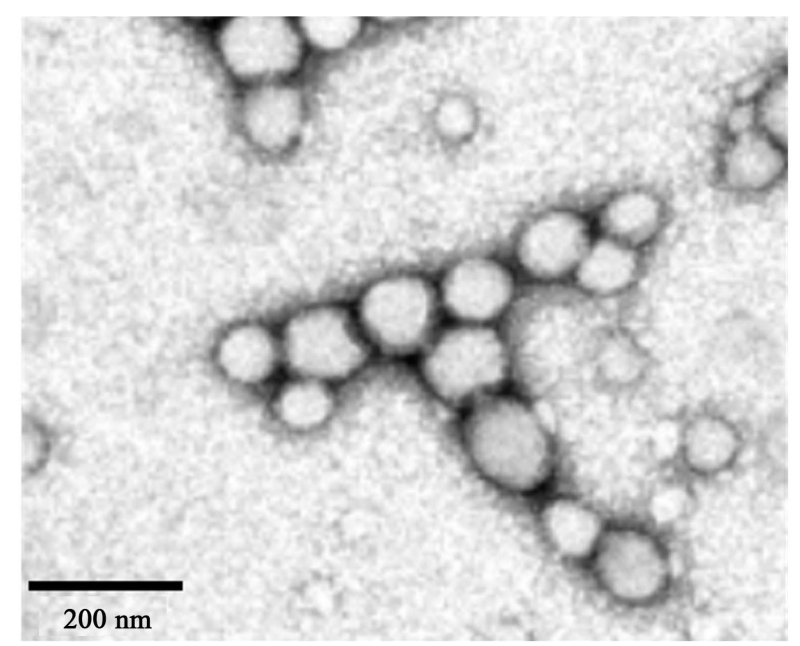

Figure 1. Transmission electron microscope (TEM) images of PLGA NPs. Image is representative of samples.

Table 1. Amino acid sequence of recombinant human mannose-binding protein C/MBL2.

ETVTCEDAQKTCPAVIACSSPGINGFPGKDGRDGTKGEKGEPGQGLRGLQGPPGKLGPP GNPGPSGSPGPKGQKGDPGKSPDGDSSLAASERKALQTEMARIKKWLTFSLGKQVGNKFFLTN GEIMTFEKVKALCVKFQASVATPRNAAENGAIQNLIKEEAFLGITDEKTEGQFVDLTGNR LTYTNWNEGEPNNAGSDEDCVLLLKNGQWNDVPCSTSHLAVCEFPIVDHHHHHH 


\subsection{Binding of Modified and Unmodified Biodegradable Nanoparticles with HMBP Monitored by Fluorescence Spectroscopy}

Since the protein contains tryptophan residues within its structure, the fluorescence emission of tryptophan was used to monitor its binding with the NPs. The maximum absorption wavelength for the HMBP determined to be $280 \mathrm{~nm}$ (data not shown) by a hybrid multi-mode microplate reader (Synergy H1, BioTek, Winooski, VT), and this wavelength was used as an excitation wavelength in the binding assay. Various concentrations of the HMBP were prepared, and their spectrum was taken using the micro plate reader at $280 \mathrm{~nm}$ excitation wavelength to determine the working concentration range as well as the maximum fluorescence emission wavelength to be used for the binding assay. From the spectra obtained, the right concentration for the binding assay was identified and the maximum emission wavelength was determined to be $330 \mathrm{~nm}$ (data not shown). The binding assay was performed by incubating $25 \mu \mathrm{L}$ of various concentrations $(0.004 \mu \mathrm{M}-0.8 \mu \mathrm{M})$ of PLGA-COOH or PLGA-PEG-NH $\mathrm{N}_{2}$ with 75 $\mu \mathrm{L}$ of HMBP to get a final concentration of $1 \mu \mathrm{M}$ HMBP. The sample was incubated for $40 \mathrm{~min}$ in phosphate buffered saline (PBS, pH 7.4) at $37^{\circ} \mathrm{C}$ on a shaker incubator with a $100 \mathrm{rpm}$ and the emission spectra at $330 \mathrm{~nm}$ were taken using the excitation wavelength of $280 \mathrm{~nm}$. PBS and HMBP solutions were used as negative and positive controls, respectively.

\subsection{Determination of Protein Corona Formation on Unmodified and Modified Biodegradable NPs}

The size of PLGA-COOH and PLGA-PEG- $\mathrm{NH}_{2}$ NPs in the absence and presence HMBP was monitored by DLS (Zetasizer Nano ZS, Malvern Instruments, Worcestershire, UK). PLGA-COOH or PLGA-PEG- $\mathrm{NH}_{2}$ biodegradable NPs with various concentrations $(0.004 \mu \mathrm{M}-0.8 \mu \mathrm{M})$ were incubated with $1 \mu \mathrm{M}$ HMBP in PBS buffer at $\mathrm{pH}$ 7.4. The samples were incubated for $40 \mathrm{~min}$ at $37^{\circ} \mathrm{C}$ in a shaker incubator with $100 \mathrm{rpm}$, and change in the size of the NPs determined in the absence and presence of HMBP.

\subsection{ELISA Binding Assay for the Interaction of Recombinant Human Mannose-Binding Protein with Mannan from Saccharomyces cerevisiae}

The binding of Recombinant Human Mannose-Binding Protein C/MBL-2 (HMBP) to Mannan from Saccharomyces cerevisiae was done by coating high biding 96-well plates with $100 \mu \mathrm{l}$ of $0.02 \mathrm{mg} / \mathrm{ml}$ Mannan dissolved in a coating buffer $\left(0.75 \mathrm{~g} \mathrm{NaCO}_{3}, 1.47 \mathrm{~g} \mathrm{NaHCO}_{3}\right.$ in $250 \mathrm{ml}$ distilled $\left.\mathrm{H}_{2} \mathrm{O}\right)$ at $\mathrm{pH} 9.8$ and incubating for $2 \mathrm{~h}$ at room temperature. After 3 washes with TBS (Tris buffered saline containing $0.05 \mathrm{M}$ Tris- $\mathrm{HCl}, 0.15 \mathrm{M} \mathrm{NaCl}$ at $\mathrm{pH} 7.4$ ), nonspecific binding was blocked by incubating the wells with $50 \mu \mathrm{L}$ of PBS containing $1 \% \mathrm{w} / \mathrm{v}$ BSA for $1 \mathrm{~h}$ at room temperature. The wells were washed again three times with tween/TBS buffer, pH 7.4 containing $0.15 \mathrm{mM} \mathrm{CaCl}_{2}$. Then, Recombinant $\mathrm{Hu}$ man Mannose-Binding Protein C/MBL-2 (HMBP) was diluted to create various 
concentrations in the calcium-containing blocking/binding buffer (1\% w/v BSA in TBS) and added to the wells to give a final volume of $100 \mu \mathrm{L} /$ well and incubated for $2 \mathrm{~h}$ with blocking/binding buffer at room temperature to allow binding. After 3 washes, the plate was incubated for $2 \mathrm{~h}$ at room temperature with Sprotein-HRP conjugate (Novagen) at a verified optimal dilution of 1:5000 in TBS buffer, pH 7.4 containing $0.15 \mathrm{mM} \mathrm{CaCl}_{2}$. Followed by washing 3 times with wash buffer containing $0.15 \mathrm{mM} \mathrm{CaCl}_{2}$, the plate was incubated with $50 \mu \mathrm{l}$ of ABTS peroxidase substrate (ABTS (2,2'-azino-di [3-ethylbenzthiazoline] sulfonate)), for $30 \mathrm{~min}$ at room temperature. Then, the UV absorbance of each well was scanned in the wavelength range of $300 \mathrm{~nm}$ to $500 \mathrm{~nm}$.

\section{Result and Discussion}

Unmodified poly (D, L-lactide-co-glycolide) (PLGA-COOH) and modified (PLGA-PEG-NH $\mathrm{N}_{2}$ ) biodegradable NPs were used to study the effect of surface modification in the interaction of NPs with HMBP which is a part of the innate immune system proteins. The spectrum and the corresponding bar graph depicted in Figure 2(a) \& Figure 2(b) show that the emission fluorescence of the protein decreases as the concentration of the unmodified NPs increases, indi-

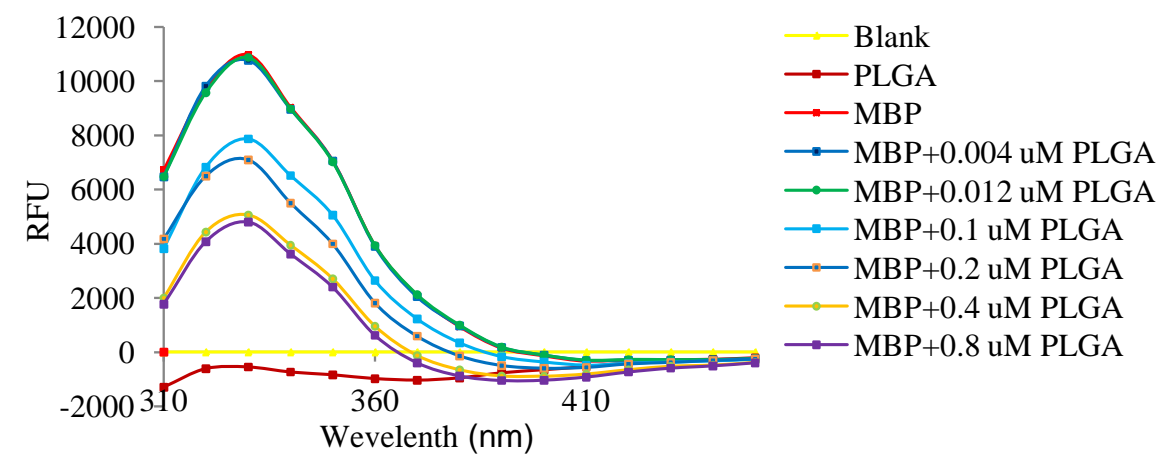

(a)

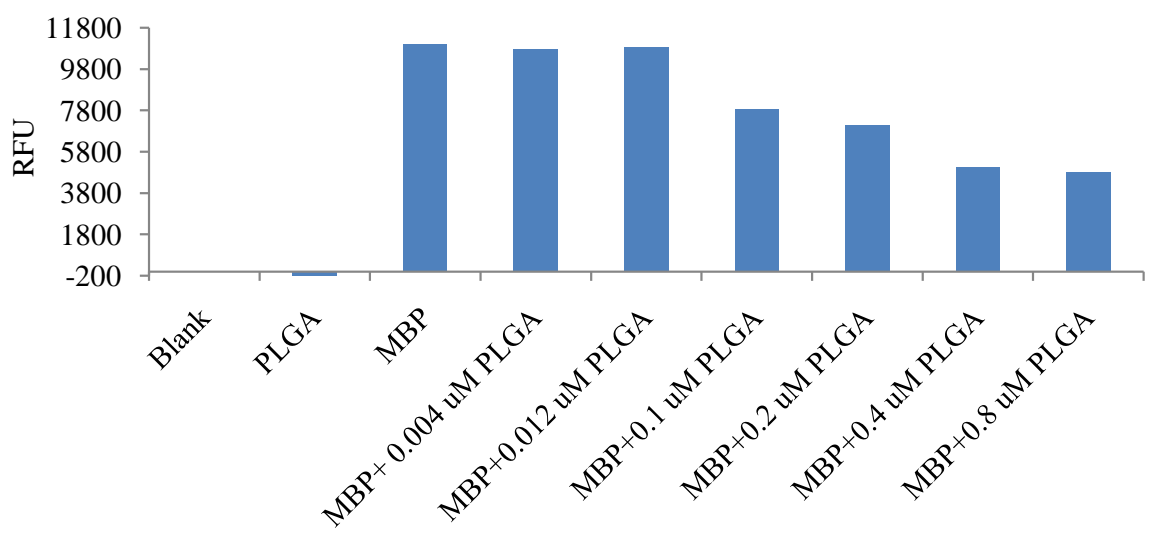

(b)

Figure 2. (a) Fluorescence spectra and (b) the corresponding bar graph showing the binding of Human Mannose Binding Protein with unmodified PLGA NPs (PLGA$\mathrm{COOH}) .1 \mu \mathrm{M}$ HMBP was titrated with various concentrations of NPs $(0.004 \mu \mathrm{M}-0.8$ $\mu \mathrm{M})$. 
cating that the unmodified NPs bind to the protein. On the other hand, the spectrum and the corresponding bar graph depicted in Figure 3(a) \& Figure 3(b) reveal that as the concentration of the modified NPs increases so does the fluorescence emission of the protein indicating that there is also binding between the protein and NPs. In this case, however, the binding site may be different from that of modified NPs. The increase in fluorescence could be due to the fact that the binding of the modified NPs causes a conformational change of the protein, thereby exposing or putting the tryptophan in an altered environment. It is believed that one of this binding must have taken place in the carbohydrate recognition domain. In order to verify the presence of active carbohydrate recognition domain, ELISA Mannose-binding assay experiment was done by immobilizing $0.02 \mathrm{mg} / \mathrm{ml}$ of Mannan from Saccharomyces cerevisiae (known binding ligand for the Protein) and incubating it with various concentrations of HMBP $(0.8 \mathrm{mM}, 1.5 \mathrm{mM}, 3 \mathrm{mM}, 8 \mathrm{mM})$. The result indicated that as the concentration of HMBP increases so does the absorption showing the presence of active carbohydrate binding domain as expected (data not shown). A study us-

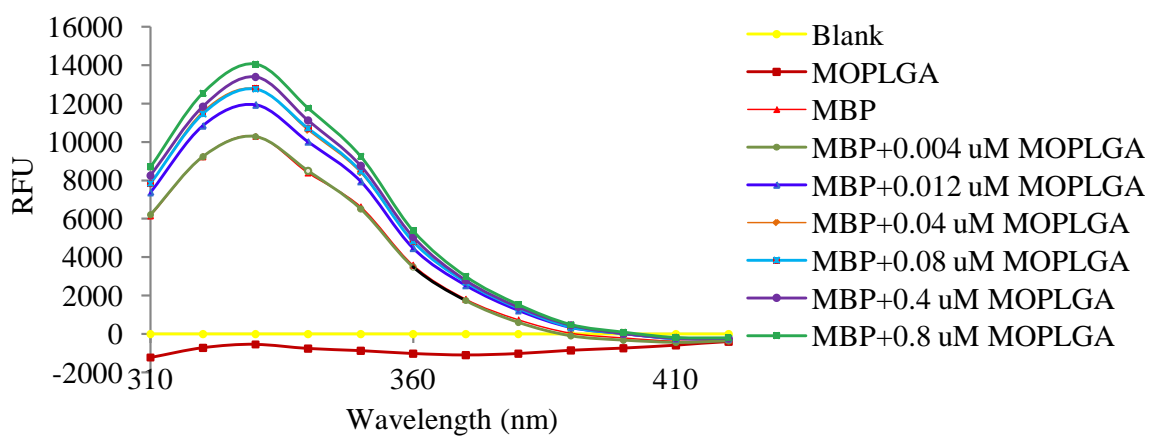

(a)

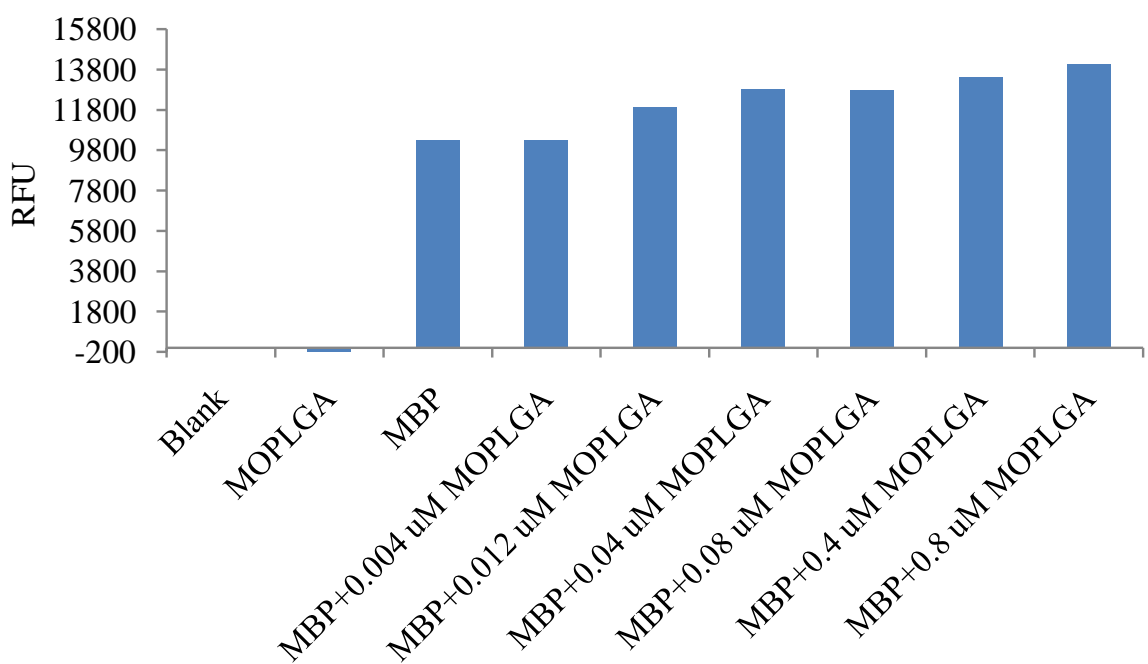

(b)

Figure 3. (a) Fluorescence spectra and (b) the corresponding bar graph showing the binding of Human Mannose Binding Protein) with Modified PLGA NPs (PLGAPEG-NH $\left.\mathrm{N}_{2}\right) .1 \mu \mathrm{M}$ HMBP was titrated with various concentrations of Modified NPs $(0.004$ $\mu \mathrm{M}-0.8 \mu \mathrm{M})$. 
ing DLS shows the size of both modified and unmodified NPS increased upon binding to the protein indicating protein corona formation. The result from fixed concentration of HMBP $(1 \mu \mathrm{M})$ titrated against various concentrations of modified or unmodified NPs show that an increase in the ratio of protein to NPs leads to an increase in the size of NPs (Figure 4 \& Figure 5). Similar experiments with fixed concentration of NPs against various concentrations of HMBP also showed same trend (Figure 6 \& Figure 7).

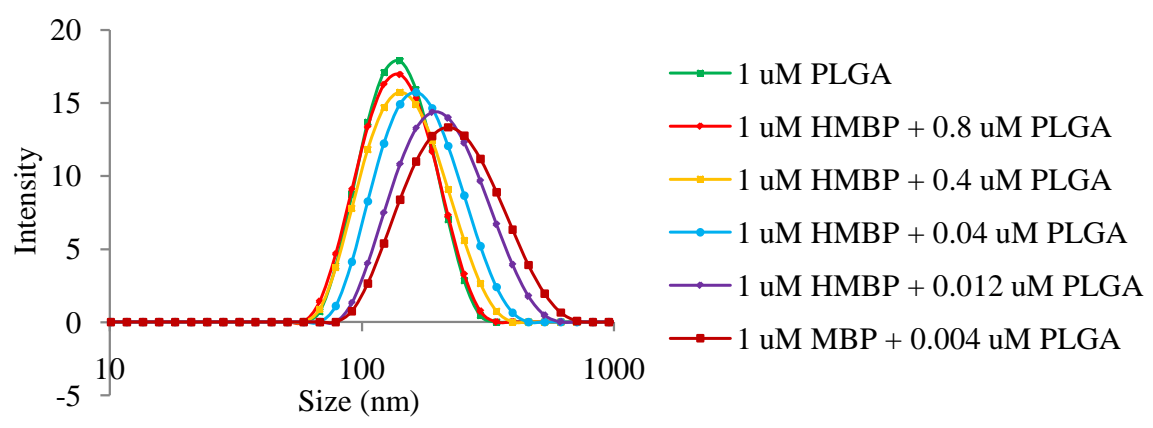

Figure 4. Dynamic light scattering measurement showing an increase in the size of unmodified PLGA NPs (PLGA-COOH) at various proportion of HMBP to NPs. $1 \mu \mathrm{M}$ HMBP incubated with various concentrations of NPs $(0.012 \mu \mathrm{M}-0.4 \mu \mathrm{M})$. The size of NPs increased as the proportion of protein increased.

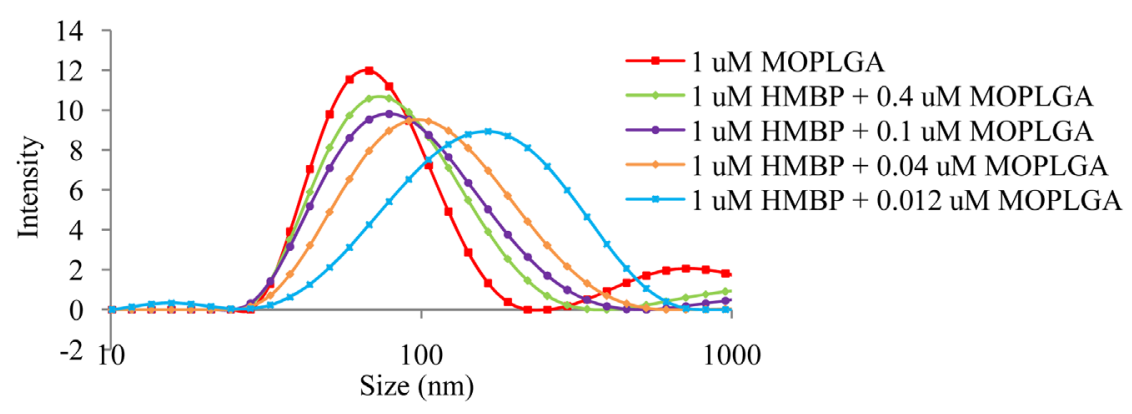

Figure 5. Dynamic light scattering measurement showing an increase in the size of modified PLGA NPs (PLGA-PEG-NH $\mathrm{NH}_{2}$ ) at various proportion of HMBP to NPs. $1 \mu \mathrm{M}$ HMBP incubated with various concentrations of NPs $(0.012 \mu \mathrm{M}-0.4 \mu \mathrm{M})$. The size of NPs increased as the proportion of protein increased.

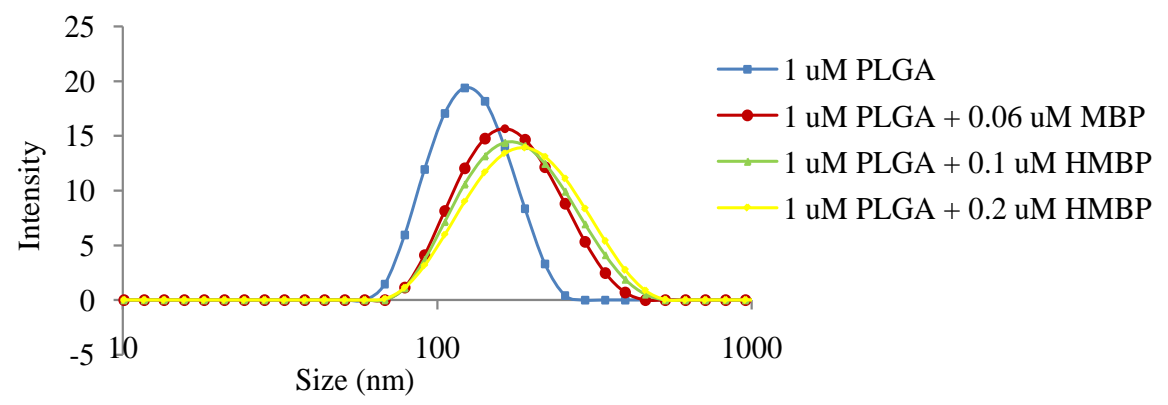

Figure 6. Dynamic light scattering measurement showing an increase in the size of unmodified PLGA NPs (PLGA) at various concentrations of HMBP. $1 \mu \mathrm{M}$ HMBP incubated with various concentrations of NPs $(0.06 \mu \mathrm{M}-0.2 \mu \mathrm{M})$. The size of NPs increased as the concentration of protein increased. 


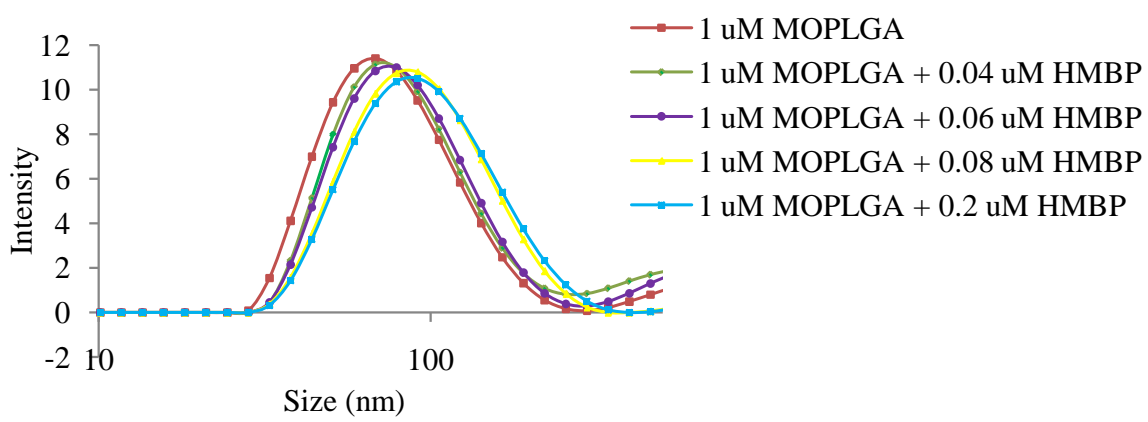

Figure 7. Dynamic light scattering measurement showing an increase in the size of modified PLGA NPs (PLGA-PEG-NH $\mathrm{N}_{2}$ ) with various concentrations of HMBP. $1 \mu \mathrm{M}$ PLGAPEG-NH $\mathrm{N}_{2}$ incubated with various concentrations of HMBP $(0.04 \mu \mathrm{M}-0.2 \mu \mathrm{M})$. The size of NPs increased as the concentration of protein increased.

\section{Conclusion}

Modification of the surface of biodegradable NPs such as PLGA affects their interaction with Collectin proteins (Mannose Binding Proteins). Based on their modification they could be recognized by the host cell innate defense mechanism as a threat to the organism and could be quickly eliminated from the host cell. On the other hand, drug delivery NPs designed with appropriate modifications for a particular target could avoid premature elimination from the system. Surface modification of NPs is an attractive and promising area to be explored, and has great potential for making efficient drug delivery systems. We have shown here that modified PLGA (PLGA-PEG- $\mathrm{NH}_{2}$ ) displayed different binding profiles from unmodified PLGA. However, further competition binding study will be needed to determine the specificity of the binding. Moreover, a complete understanding of modified NPs' interaction with a range of proteins in the innate immune system will provide a pool of appropriate modifications for effective drug delivery system. In future work we envision to achieving this by using different modifications and various proteins of the immune system to create a data base. Once these objectives are achieved, immune assay could be used to monitor cellular immune responses for better understanding of its application.

\section{Acknowledgements}

The authors would like to express their appreciation for the support from the following institutions for resources and facilities: 1. Center of Excellence for Emerging and Zoonotic Animal Diseases (CEEZAD) at Kansas State University: (Dr. Jürgen A. Richt, Director, and Dr. Jessica Green, Project Coordinator), 2. Nanotechnology Innovation Center of Kansas State (NICKS) at Kansas State University. This work was funded by the US Department of Homeland Security (DHS) Science \& Technology (S \& T) Directorate Office of University Programs (Summer Research Team Program for Minority Serving Institutions).

\section{References}

[1] Tnvkv, P. and Elumalai, E.K. (2011) Biofabrication of Ag Nanoparticles Using Mo- 
ringaoleifera Leaf Extract and Their Antimicrobial Activity. Asian Pacific Journal of Tropical Biomedicine, 1, 439-442. https://doi.org/10.1016/S2221-1691(11)60096-8

[2] Mritunjai, S., Shinji, N.S., Prasad, S. and Gambhir, I.S. (2008) Nanotechnology in Medicine and Antibacterial Effect of Silver Nanoparticles. Digest Journal of Nanomaterials and Biostructures, 3, 115-122.

[3] Justin, T.S. and Thomas, J.W. (2012) Antimicrobial Applications of Nanotechnology: Methods and Literature. International Journal of Nanomedicine, 7, 2767-2781.

[4] Guthrie, K.M., Agarwal, A., Tackes, D.S., Johnson, K.W., Abbott, N.L. and Murphy, C.J. (2012) Antibacterial Efficacy of Silver-Impregnated Polyelectrolyte Multilayer Immobilized on a Biological Dressing in a Murine Wound Infection Model. Annals of Surgery, 256, 371-377. https://doi.org/10.1097/SLA.0b013e318256ff99

[5] Jain, P. and Pradeep, T. (2005) Potential of Silver Nanoparticle-Coated Polyurethane Foam as an Antibacterial Water Filter. Biotechnology and Bioengineering, 90, 59-63. https://doi.org/10.1002/bit.20368

[6] Oliver, G., Tünde, V.S., Priscilla, S.B., Amer, E.V., Daniel, E.S., Michael, O., Regine, L. and Katharina, M. (2010) Silver Coordination Polymers for Prevention of Implant Infection: Thiol Interaction, Impact on Respiratory Chain Enzymes, and Hydroxyl Radical Induction. Antimicrob Agents Chemother, 54, 4208-4218. https://doi.org/10.1128/AAC.01830-09

[7] Li, D., Diao, J., Zhang, J. and Liu, J. (2011) Fabrication of New Chitosan-Based Composite Sponge Containing Silver Nanoparticles and Its Antibacterial Properties for Wound Dressing. Journal of Nanoscience and Nanotechnology, 11, 4733-8. https://doi.org/10.1166/jnn.2011.4179

[8] Catalina, M.J. and Eric, M.V.H. (2010) A Review of the Antibacterial Effects of Silver Nanomaterials and Potential Implications for Human Health and the Environment. Journal of Nanoparticle Research, 12, 1531-1551. https://doi.org/10.1007/s11051-010-9900-y

[9] Consumer Products Inventory (2013) Project on Emerging Nanotechnologies. http://www.nanotechproject.org/cpi

[10] Hans, M.L. and Lowman, A.M. (2002) Biodegradable Nanoparticles for Drug Delivery and Targeting. Current Opinion in Solid State and Materials Science, 6, 319327. https://doi.org/10.1016/S1359-0286(02)00117-1

[11] Jayanth, P. and Vinod, L. (2003) Biodegradable Nanoparticles for Drug and Gene Delivery to Cells and Tissue. Advanced Drug Delivery Review, 55, 329-347. https://doi.org/10.1016/S0169-409X(02)00228-4

[12] Avnesh, K., Sudesh, K.Y. and Subhash, C.Y. (2010) Biodegradable Polymeric Nanoparticles Based Drug Delivery System. Colloids and Surfaces Biointerfaces, 75, 1-18. https://doi.org/10.1016/j.colsurfb.2009.09.001

[13] Liang, X., Fan, J., Zhao, Y., Cheng, M., Wang, X., Jin, R. and Sun, T. (2017) A Targeted Drug Delivery System Based on Folic Acid-Functionalized Upconversion Luminescent Nanoparticles. Journal of Biomaterials Applications, 31, 1247-1256. https://doi.org/10.1177/0885328217701289

[14] Hirenkumar, K.M. and Steven, J.S. (2011) Poly Lactic-Co-Glycolic Acid (PLGA) as Biodegradable Controlled Drug Delivery Carrier. Polymers, 3, 1377-1397. https://doi.org/10.3390/polym3031377

[15] Nguyen, T.D.T., Pitchaimani, A. and Aryal, S. (2016) Engineered Nanomedicine with Alendronic Acid Corona Improves Targeting to Osteosarcoma. Scientific Reports, 6, Article ID: 36707. https://doi.org/10.1038/srep36707

[16] Couvreur, P. (2013) Perspectives and Prospects, Nanoparticles in Drug Delivery: 
Past, Present and Future. Advanced Drug Delivery Reviews, 65, 21-23. https://doi.org/10.1016/j.addr.2012.04.010

[17] Kona, S., Specht, D., Rahimi, M., Shah, B.P., Gilbertson, T.A. and Nguyen, K.T. (2012) Targeted Biodegradable Nanoparticles for Drug Delivery to Smooth Muscle Cells. Journal of Nanoscience and Nanotechnology, 12, 236-244. https://doi.org/10.1166/jnn.2012.5131

[18] Sneha, A.K. and Si-Shen, F. (2011) Effects of Surface Modification on Delivery Efficiency of Biodegradable Nanoparticles across the Blood-Brain Barrier. Nanomedicine, 6, 377-394. https://doi.org/10.2217/nnm.10.131

[19] Kulkarni, S.A. and Feng, S.S. (2013) Effects of Particle Size and Surface Modification on Cellular Uptake and Biodistribution of Polymeric Nanoparticles for Drug Delivery. Pharmaceutical Research, 30, 2512-2522.

https://doi.org/10.1007/s11095-012-0958-3

[20] Cristina, F., Gabriela, C., Montserrat, M., Maria, P.V., Conxita, S. and Christine, V. (2015) Interactions of PLGA Nanoparticles with Blood Components: Protein Adsorption, Coagulation, Activation of the Complement System and Hemolysis Studies. Nanoscale, 7, 6045-6058. https://doi.org/10.1039/C5NR00733J

[21] Atsutoshi, Y., Egil, L., Robin, R.I., Elaine, T., Roman, D. and Douglas, G. (1999) Cutting Edge: Recognition of Gram-Positive Bacterial Cell Wall Components by the Innate Immune System Occurs Via Toll-Like Receptor. The Journal of Immunolo$g y, 163,1-5$.

[22] Ruslan, M. and Jr. Charles, A.J. (2002) Decoding the Patterns of Self and Nonself by the Innate Immune System. Science, 296, 298-300.

https://doi.org/10.1126/science.1068883

[23] Zolnik, B.S., González-Fernández, A., Sadrieh, N. and Dobrovolskaia, M.A. (2010) Minireview: Nanoparticles and the Immune System. Endocrinology, 151, 458-465. https://doi.org/10.1210/en.2009-1082

[24] Marina, A.D., Parag, A., Jennifer, B.H. and Scott, E.M. (2008) Preclinical Studies to Understand Nanoparticle Interaction with the Immune System and Its Potential Effects on Nanoparticle Biodistribution. Molecular Pharmaceutics, 5, 487-495. https://doi.org/10.1021/mp800032f

[25] Ishida, T., Wang, X., Shimizu, T., Nawata, K. and Kiwada, H. (2007) PEGylated Liposomes Elicit an Anti-PEG IgM Response in a T Cell-Independent Manner. Journal of Controlled Release, 122, 349-355. https://doi.org/10.1016/j.jconrel.2007.05.015

[26] Wang, X., Ishida, T. and Kiwada, H. (2007) Anti-PEG IgM Elicited by Injection of Liposomes is Involved in the Enhanced Blood Clearance of a Subsequent Dose of PEGylated Liposomes. Journal of Controlled Release, 119, 236-244.

https://doi.org/10.1016/j.jconrel.2007.02.010

[27] Kalkanidis, M., Pietersz, G.A., Xiang, S.D., Mottram, P.L., Crimeen-Irwin, B., Ardipradja, K. and Plebanski, M. (2006) Methods for Nano-Particle Based Vaccine Formulation and Evaluation of Their Immunogenicity. Methods, 40, 20-29. https://doi.org/10.1016/j.ymeth.2006.05.018

[28] Mitchell, L.A., Lauer, F.T., Burchiel, S.W. and McDonald, J.D. (2009) Mechanisms for How Inhaled Multiwalled Carbon Nanotubes Suppress Systemic Immune Function in Mice. Nature Nanotechnology, 4, 451-456. https://doi.org/10.1038/nnano.2009.151

[29] Melody, A., Swartz, J.A. and Hubbell, S.T.R. (2008) Lymphatic Drainage Function and Its Immunological Implications: From Dendritic Cell Homing to Vaccine Design. Seminars in Immunology, 20, 147-156. 
https://doi.org/10.1016/j.smim.2007.11.007

[30] Manolova, V., Flace, A., Bauer, M., Schwarz, K., Saudan, P. and Bachmann M.F. (2008) Nanoparticles Target Distinct Dendritic Cell Populations According to Their Size. European Journal of Immunology, 38, 1404-1413. https://doi.org/10.1002/eji.200737984

[31] Nygaard, U.C., Hansen, J.S., Samuelsen, M., Alberg, T., Marioara, C.D. and Løvik, M. (2009) Single-Walled and Multi-Walled Carbon Nanotubes Promote Allergic Immune Responses in Mice. Toxicological Sciences, 109, 113-123. https://doi.org/10.1093/toxsci/kfp057

[32] Koenraad, van de W.J., van Golde, L.M.G. and Batenburg, J.J. (2004) Collectins Players of the Innate Immune System. European Journal of Biochemistry, 271, 1229-1249. https://doi.org/10.1111/j.1432-1033.2004.04040.x

[33] Holmskov, U.L. (2000) Collectins and Collectin Receptors in Innate Immunity. APMIS. Supplementum, 100, 1-59. https://doi.org/10.1111/j.1600-0463.2000.tb05694.x

[34] Hoppe, H.J. and Reid, K.B. (1994) Collectins-Soluble Proteins Containing Collagenous Regions and Lectin Domains and Their Roles in Innate Immunity. Protein Science, 3, 1143-1158. https://doi.org/10.1002/pro.5560030801

[35] Nguyen, T.D.T., Pitchaimani, A., Koirala, M.B., Muhammad, F. and Aryal, S. (2016) Engineered Biomimetic Nanoabsorbent for Cellular Detoxification of Chemotherapeutics. RSC Advances, 6, 33003-33008. https://doi.org/10.1039/C6RA02026G

[36] Aryal, S., Key, J., Stigliano, C., Ananta, J.S., Zhong, M. and Decuzzi, P. (2013) Engineered Magnetic Hybrid Nanoparticles with Enhanced Relaxivity for Tumor Imaging. Biomaterials, 34, 7725-7732. https://doi.org/10.1016/j.biomaterials.2013.07.003

Submit or recommend next manuscript to SCIRP and we will provide best service for you:

Accepting pre-submission inquiries through Email, Facebook, LinkedIn, Twitter, etc. A wide selection of journals (inclusive of 9 subjects, more than 200 journals)

Providing 24-hour high-quality service

User-friendly online submission system

Fair and swift peer-review system

Efficient typesetting and proofreading procedure

Display of the result of downloads and visits, as well as the number of cited articles

Maximum dissemination of your research work

Submit your manuscript at: http://papersubmission.scirp.org/

Or contact anp@scirp.org 